\section{GOSPODARKA NARODOWA}

p-ISSN: 0867-0005

e-ISSN: 2300-5238

\title{
The Dynamics of Unemployment in Poland from 1992 to $2017^{1}$
}

\begin{abstract}
This article examines two approaches to the dynamics of unemployment in Poland. The first approach is based on the theory of a natural rate of unemployment. Under this theory, the economy can depart from the natural rate of unemployment in the short term due to nominal shocks, but in the long term the economy is expected to achieve an equilibrium indicated by the natural rate of unemployment. The second approach to the dynamics of unemployment is the so-called hysteresis of unemployment theory. According to this theory, all shocks to unemployment will have a permanent effect on the natural rate of unemployment. Testing these two theories amounts to testing stationarity of the series. If the unemployment rate is a non-stationary series with a unit root, then the hysteresis-in-unemployment hypothesis has to be accepted. On the other hand, if the unemployment rate is a stationary series then the hysteresis hypothesis is rejected in favour of the natural rate theory. In the study, the rate of unemployment in Poland is analysed in the period from 1992 (Q2) to 2017 (Q4). Threshold autoregressive model applied to the data indicates that the unemployment rate in Poland is a nonlinear process and, therefore, supports the hysteresis of unemployment theory.
\end{abstract}

Keywords: unemployment, hysteresis, threshold autoregression model, unit root tests

JEL classification codes: C22, J64

Article submitted April 25, 2018, accepted for publication January 16, 2019.

* University of Agriculture in Kraków, Institute of Economic and Social Sciences, Department of Economics and Economic Policy; e-mail: andrzej.pisulewski@gmail.com

1 The research was supported by the Polish Ministry of Science and Higher Education using funds for statutory activities by young researchers. The author would like to thank the anonymous reviewers for their helpful comments and suggestions. 


\section{Introduction}

There are two alternative approaches in the literature on the dynamics of unemployment. The first approach is based on the theory of the natural rate of unemployment introduced by Friedman [1968] and Phelps [1967, 1968]. Under this theory, the economy can depart from the natural rate of unemployment in the short run due to nominal shocks. However, in the long run, the economy is expected to achieve an equilibrium indicated by the natural rate of unemployment. The second approach to the dynamics of unemployment was presented by Blanchard and Summers [1986], who proposed what is known as the hysteresis theory. The authors suggested that high and persistent unemployment is the result of nominal or real shocks. They argued that theories advocating the existence of a natural rate of unemployment or a non-accelerating inflation rate of unemployment (NAIRU) failed to identify the endogenous impact of a surge in unemployment on the long-run natural rate.

The assessment of the hysteresis issue has important policy implications. Blanchard and Summers [1986] claim that their wage-barraging model, which explains the causes of the hysteresis of unemployment, indicates that demand expansionary policy can have a long-term impact on the level of unemployment. The demand shocks triggered by this kind of policy can lower unemployment regardless of its source. However, according to Blanchard and Summers [1986], such positive effects can only be achieved when the demand expansionary policy is unexpected. Also, supply shocks can cause similar positive effects.

According to the statistical approach, the two above-mentioned theories can be described in the following way: the natural rate hypothesis implies that the deviations in unemployment from the natural rate are temporary, and therefore the unemployment rate will be a stationary series with a stable long-run steady state. Meanwhile, the strictest form of hysteresis implies that all shocks to unemployment will result in permanent effects and the unemployment rate will be a non-stationary series with a unit root.

In literature, there are several approaches applied in testing hysteresis in unemployment. The first approach is based on the classical unit root tests, i.e. usually the Augmented Dickey-Fuller (ADF) or Phillips-Perron tests. The second strand of literature considers the existence of structural breaks in the unemployment rate. In the third approach, panel data is used to increase the power of the tests. Panel unit root tests can also account for structural breaks in the unemployment rate. A thorough review of the applied studies concerning testing hysteresis in unemployment is offered by Lee and Chang [2008].

It is well known that unemployment rises faster during a recession than it falls during a boom [Akdoğan, 2017]. Due to this asymmetry, conventional unit root tests fail to reject the non-stationary hypothesis, since, as pointed out by Caner and Hansen [2001], they do not differentiate nonlinearity from non-stationarity. Therefore, there is a need to account for this asymmetry. The first approach to address the asymmetry is the above-mentioned unit root tests with structural breaks. It was proved that unit root tests, which ignore the 
possibility of structural breaks, may erroneously show the presence of hysteresis. For instance, Papell et al. [2000], by introducing structural breaks, rejected the null hypothesis of non-stationarity in 10 of 16 OECD countries, in which they previously failed to reject the null hypothesis using the ADF test. The second approach is the use of nonlinear models and the particularly appealing threshold unit root test proposed by Caner and Hansen [2001].a

Taking the above approaches into account, the main aim of this study is to check the hypothesis of hysteresis in unemployment in Poland. Another aim is to determine whether the rate of unemployment in Poland is a nonlinear process. Finally, regarding the above-presented shortcomings of conventional unit root tests, it would be interesting to verify the hypothesis of the unemployment rate in Poland with a threshold unit root test. Taking into account economic policy, the failure to reject the null hypothesis of non-stationarity means that shocks to the unemployment rate will have a permanent effect on its level, while nonlinearity of the unemployment rate indicates that its response to shocks is asymmetric.

The possibility of hysteresis of unemployment in Poland was first pointed out by Wojtyna [1994]. While the issue of estimating the natural rate of unemployment for the Polish economy was frequently analysed, for example by Socha and Sztanderska [2000], Kwiatkowski [2002], Arendt [2005], Kelm [2009], Roszkowska [2013], and Welfe and Leszkiewicz-Kędzior [2013], the problem of hysteresis in unemployment in Poland was rarely studied. However, some of the above-mentioned studies, i.e. Kwiatkowski [2002] and Kelm [2009], suggested that there might be hysteresis in unemployment in Poland since the estimated natural rate of unemployment changed in the same direction as the observed rate of unemployment. The exceptions are the studies of Arendt [2005] and Mielich-Iwanek [2009]. Internationally, research by LeónLedesma and McAdam [2004], Yilanci [2008] and Akdoğan [2017] yielded findings on hysteresis in unemployment in Poland.

The remaining part of this paper is structured in the following way: section 2 presents the employed methodology, namely the estimation procedure for TAR models and the testing procedure for nonlinearity and unit root; in section 3, the data used in the study is described; in the fourth section the main empirical findings are presented; and the last section concludes.

\section{The Threshold Autoregression (TAR) Model}

In this section, the estimation procedure for threshold autoregression (TAR) models and the testing procedure for nonlinearity and non-stationarity in TAR models are briefly outlined. A thorough review of the development of TAR models is offered in Tong [2011], while the possible application of such models in economics is explored in Hansen [2011].

The model used in this study is the following two-regime threshold autoregression (TAR): 


$$
\Delta y_{t}=x_{t}^{\prime} \theta_{1} 1_{\left\{z_{t-1}<\lambda\right\}}+x_{t}^{\prime} \theta_{2} 1_{\left\{z_{t-12 \lambda}\right\}}+e_{t}
$$

$t=1, \ldots T$, where $x_{t}=\left(y_{t-1} r_{t}^{\prime} \Delta y_{t-1} \ldots \Delta y_{t-k}\right)^{\prime}, 1_{\{-\}}$is the indicator function, $e_{t}$ is the iid error, and the threshold variable is of the following form: $Z_{t-1}=y_{t-1}-y_{t-1-m}$, for delay parameters $m \geq 1$, and $r_{t}$ is a vector of deterministic components including an intercept and possibly a linear trend. The threshold $\lambda$ is unknown. It takes on values in the interval $\lambda \in \Lambda=\left[\lambda_{1}, \lambda_{2}\right]$ where $\lambda_{1}$ and $\lambda_{2}$ are picked, so that $P\left(Z_{t} \leq \lambda_{1}\right)=\pi_{1}>0$ and $P\left(Z_{t} \leq \lambda_{2}\right)=\pi_{2}<1$. It is convenient to treat $\pi_{1}$ and $\pi_{2}$ symmetrically so that $\pi_{2}=1-\pi_{1}$, which imposes the restriction that no "regime" has less than $\pi_{1} \%$ of the total sample. In this study $\pi_{1}$ is set to $15 \%$. The parameters $\theta_{1}$ are the slopes when $\mathrm{Z}_{\mathrm{t}-1}<\lambda$, and $\theta_{2}$ are the slopes when $Z_{t-1} \geq \lambda$. For practical reasons it is useful to partition the vectors $\theta_{1}$ and $\theta_{2}$ in the following way:

$$
\theta_{1}=\left[\begin{array}{c}
\rho_{1} \\
\alpha_{1} \\
\beta_{1}
\end{array}\right], \quad \theta_{2}=\left[\begin{array}{c}
\rho_{1} \\
\alpha_{2} \\
\beta_{2}
\end{array}\right]
$$

where $\rho_{1}$ and $\rho_{2}$ are the slope coefficients on $\mathrm{y}_{\mathrm{t}-1}, \alpha_{1}$ and $\alpha_{2}$ are the slopes on the constant term, and $\beta_{1}, \beta_{2}$ are the slope coefficients on $\left(\Delta \mathrm{y}_{\left.\mathrm{t}-1, \cdots, \Delta \mathrm{y}_{\mathrm{t}-\mathrm{k}}\right)}\right)$ in the two regimes.

The TAR model in (1) can equivalently be written as:

$$
\Delta y_{t}=x_{t}(\lambda)^{\prime} \theta+e_{t}
$$

where $\theta=\left(\theta_{1}^{\prime}, \theta_{2}^{\prime}\right)^{\prime}$. The above equation can be estimated by least squares (LS), which is equivalent to the maximum likelihood estimation under the auxiliary assumption that $e_{t}$ is iid $N\left(0, \sigma^{2}\right)$. The most convenient method to obtain LS estimates is to use sequential conditional LS. For a given value of each $\lambda$, the LS estimate of $\theta$ is:

$$
\hat{\theta}(\lambda)=\left(\sum_{t=1}^{T} x_{t}(\lambda) x_{t}(\lambda)^{\prime}\right)^{-1}\left(\sum_{t=1}^{T} x_{t}(\lambda) y_{t}\right)
$$

with residuals $\hat{e}_{t}(\lambda)=y_{t}-x_{t}(\lambda)^{\prime} \hat{\theta}(\lambda)$, and residual variance:

$$
\hat{\sigma}^{2}(\lambda)=\frac{1}{T} \sum_{t=1}^{T} \hat{e}_{t}(\lambda)^{2}
$$

The LS estimate of $\lambda$ is the value that minimises the above equation (2):

$$
\hat{\lambda}=\operatorname{argmin} \hat{\sigma}^{2}(\lambda)
$$

where $\Lambda=\left[\lambda_{1}, \lambda_{2}\right]$. 
The primary interest of this study is to find out whether the unemployment rate in Poland is a linear or nonlinear process. Consequently, the following null hypothesis will be tested: $H_{0}: \theta_{1}=\theta_{2}$. In order to test this hypothesis, the standard Wald statistic $\mathrm{W}_{\mathrm{t}}$ can be used, and it can be written in the following way:

$$
W_{T}(\lambda)=T\left(\frac{\hat{\sigma}_{0}^{2}}{\hat{\sigma}^{2}(\lambda)}-1\right)
$$

where $\hat{\sigma}^{2}$ is defined above as residual variance (2), and $\sigma_{0}^{2}$ is the residual variance from OLS estimation of the linear model, i.e. under the null hypothesis. The simulation method to calculate critical values and $p$-values for such tests for stationary data was presented by Hansen [1996]. However, if the time-series has a unit root, the bootstrap distribution will be inconsistent for the correct sampling distribution. Caner and Hansen [2001] suggested a solution to this issue taking into consideration two bootstrap methods. They refer to the first method, applicable to a stationary case, as the "unrestricted bootstrap", while referring to the other one, applicable to a unit root case, as the "restricted bootstrap". Following Caner and Hansen [2001], the unrestricted bootstrap procedure can be described as follows: let $(\tilde{\rho}, \tilde{\beta}, \tilde{F})$ be estimates of $(\rho, \beta, F)$, the bootstrap distribution $W_{t}^{b}$ is a conditional distribution determined by the random inputs $(\tilde{\rho}, \tilde{\beta}, \tilde{F})$, and the estimates of $(\tilde{\rho}, \tilde{\beta})$ are obtained by OLS, while $\tilde{F}$ is the empirical distribution of the OLS residuals. Subsequently, $e_{t}^{b}$ is a random draw from $\tilde{F}$, while $y_{t}^{b}$ is generated as $\Delta y_{t}^{b}=\tilde{\rho} y_{t-1}^{b}+\tilde{\beta}^{\prime} \tilde{\Delta} y_{t-1}^{b}+e_{t}^{b}$ where $\tilde{\Delta} y_{t-1}^{b}=\left(\Delta y_{t-1}^{b}, \cdots, \Delta y_{t-k}^{b}\right)^{\prime}$. The initial values for the recursion can be set to sample values of the demeaned series. The distribution of $y_{t}^{b}$ is the bootstrap distribution of the data. Let $W_{t}^{b}$ be the threshold Wald test calculated from the $y_{t}^{b}$ series. The distribution of $W_{t}^{b}$ is the bootstrap distribution of the Wald test. Its bootstrap $p$-value is approximated by the frequency of simulated $W_{t}^{b}$ that exceed $\mathrm{W}_{\mathrm{T}}$.

The constrained bootstrap distribution is estimated by imposing the true unit root restriction i.e. $\rho=0$. As a consequence, the estimates of $(\rho, \beta, F)$ are set to $(0, \tilde{\rho}, \tilde{\beta})$, where $(\tilde{\beta}, \tilde{F})$ were defined previously. Then random samples of $y_{t}^{b}$ are generated from $\Delta y_{t}^{b}=\tilde{\beta}^{\prime} \tilde{\Delta} y_{t-1}^{b}+e_{t}^{b}$ with $e_{t}^{b}$ drawn randomly from $\tilde{F}$. These samples are unit root processes. The estimated $p$-value is obtained as previously, by calculating the percentage of the simulated $W_{t}^{b}$ that exceed the observed $\mathrm{W}_{\mathrm{T}}$. Having obtained both bootstrap $p$-values under unrestricted and restricted cases, Caner and Hansen [2001] recommend basing inference on the more conservative (larger) p-value.

The second main hypothesis to be verified concerns unit roots and stationarity in the TAR model. First, it is tested whether $\mathrm{y}_{\mathrm{t}}$ can be described as having a "unit root", and therefore the following null hypothesis is tested:

$$
H_{0}: \rho_{1}=\rho_{2}=0
$$


The parameters $\rho_{1}, \rho_{2}$ control the stationarity of the $y_{t}$ process. Moreover, the result of the test indicates whether there is hysteresis of unemployment or not. The first hypothesis to be verified is the following:

$$
H_{1}: \rho_{1}<0 \text { and } \rho_{2}<0
$$

Additionally, the partial unit root can be distinguished, in the case of which the alternative hypothesis takes the following form:

$$
H_{2}:\left\{\begin{array}{l}
\rho_{1}<0 \text { and } \rho_{2}=0 \\
\rho_{1}=0 \text { and } \rho_{2}<0
\end{array}\right.
$$

In order to test for (3) against the unrestricted alternative: $\rho_{1} \neq 0$ or $\rho_{2} \neq 0$, the Wald statistic in the following form can be used:

$$
R_{2 T}=t_{1}^{2}+t_{2}^{2}
$$

where $t_{1}$ and $t_{2}$ are the $t$ ratios for $\rho_{1}$ and $\rho_{2}$ from the OLS regression. Still, according to Caner and Hansen [2001], this statistic is ill-focused, and therefore, the simple one-sided Wald statistic should be considered as follows:

$$
R_{1 T}=t_{1}^{2} 1_{\left\{\hat{\rho}_{1}<0\right\}}+t_{2}^{2} 1_{\left\{\widehat{\rho_{2}<0}\right\}}
$$

which is testing $\mathrm{H}_{0}$ against the one-sided alternative $\rho_{1}<0$ or $\rho_{2}<0$. While this test statistic can justify the rejection of the unit root hypothesis, it cannot discriminate between the stationary case $\mathrm{H}_{1}$ and the partial unit root case $\mathrm{H}_{2}$. Therefore, following the Caner and Hansen [2001] suggestion, the individual $t$-statistics $t_{1}$ and $t_{2}$, should be investigated. Similar to their study, the negative of the $t$ statistics i.e. $-t_{1}$ and $-t_{2}$ will be considered, so that the test rejects the null hypothesis in the case of large values of the test statistic. If either $t_{1}$ or $-t_{2}$ is statistically significant, it would be consistent with the partial unit root case $\mathrm{H}_{2}$, making it possible to distinguish among $\mathrm{H}_{0}, \mathrm{H}_{1}$ and $\mathrm{H}_{2}$. All the above test statistics are continuous functions of the $t$ ratios $t_{1}$ and $t_{2}$. In order to unify the presentation, a class of test statistics is considered: $R_{T}=R\left(t_{1}, t_{2}\right)$, where $\mathrm{R}\left(\mathrm{x}_{1}, \mathrm{x}_{2}\right)$ is a continuous function of $\mathrm{x}_{1}$ and $\mathrm{x}_{2}$. To facilitate the inference process, the $R_{T}=R(\cdot, \cdot)$ is normalised, so that $\mathrm{H}_{0}$ is rejected for large values of $\mathrm{R}_{\mathrm{T}}$, as it is true for the specific tests described above. The remaining issue to be resolved is to determine the sampling distribution of the test under $\mathrm{H}_{0}$.

Caner and Hansen [2001] suggested the bootstrap methods to approximate the distributions of $\mathrm{R}_{\mathrm{T}}$. They distinguished a bootstrap distribution, which imposes an identified threshold effect or imposes an unidentified threshold effect. Furthermore, they showed that the asymptotic distribution of $\mathrm{R}_{\mathrm{T}}$ is different in those two cases, therefore the bootstrap distribution is likely to be significantly different as well. The unidentified threshold bootstrap imposes 
the following restrictions: $\theta=\theta_{1}=\theta_{2}$ and $\rho=0$. Random samples of $y_{t}^{b}$ are generated from the model $\Delta y_{t}^{b}=\tilde{\beta}^{\prime} \tilde{\Delta} y_{t-1}^{b}+e_{t}^{b}$, where $e_{t}^{b}$ is drawn randomly from $\tilde{F}$ and $\tilde{\beta}$ is obtained by OLS. Subsequently, for each $y_{t}^{b}$ sample the $R_{T}^{b}$ test statistic is calculated. The estimated bootstrap $p$-value is the percentage of the simulated $R_{T}^{b}$ that exceed the observed $\mathrm{R}_{\mathrm{T}}$.

The identified threshold bootstrap requires simulation from a unit root TAR process. To generate $y_{t}^{b}$ samples from the model (1), the following estimates obtained from the unrestricted model are used: $\left(0, \widetilde{\alpha}_{1}, \widetilde{\beta}_{1}, 0, \widetilde{\alpha_{2}}, \widetilde{\beta_{2}}, \hat{\lambda}, \tilde{F}\right)$. Again, each $R_{T}^{b}$ sample is calculated, and the estimate of the bootstrap $p$-value is the percentage of $R_{T}^{b}$ that exceed $\mathrm{R}_{\mathrm{T}}$ On the basis of a comparison of the performance of unidentified and identified threshold bootstrap procedures, Caner and Hansen [2001] recommend calculating $p$-values using the unidentified threshold bootstrap.

In this study, all the results below were obtained with the GAUSS code written by Bruce Hansen, which was downloaded from: www.ssc.wisc.edu/ bhansen. The bootstrap p-values were calculated from 10,000 replications.

\section{Macroeconomic Data}

In the study, the rate of unemployment in Poland is analysed in the period from the second quarter (Q2) of 1992 to the fourth quarter (Q4) of 2017. The unemployment rate was constructed on the basis of data obtained from the Central Statistical Office [2018a, b] as the ratio of unemployed to the total labour force. However, there are several problems with that dataset. First of all, until the fourth quarter of 1999, data were reported for the end of February, May, August and November but not on a quarterly basis. Therefore, in this study, the reported rate of unemployment until the first quarter of 1999 was treated as if it were a quarterly rate of unemployment. Secondly, some observations on the unemployment rate are missing, such as the unemployment rate for May 1999 (second quarter) and August 1999 (third quarter). While Bartosik and Mycielski [2016] used interpolation to fill in the missing data, the X-12 ARIMA programme ${ }^{2}$ was used for this study. What's more, the aforementioned programme was used to seasonally adjust the data. In Figure 1, two unemployment rate series, one not seasonally adjusted (NSA UR) and the other seasonally adjusted (SA UR), are presented.

Generally, there are three waves of unemployment that can be distinguished in Poland [Bartosik, 2012]. The first one was observable in the beginning of the country's transformation to a market economy in the early 1990 s. Unemployment rose until the first quarter of 1994 (15.93\%). Later, it declined on the whole, though with occasional spikes until the third quarter of 1998 (10.24\%). The second, strongest wave of unemployment in the Polish economy was recorded

2 The programme is available in the GRETL econometric software package. 
from 1998 to 2004. Unemployment peaked in the third quarter of 2004 when it rose to $20.67 \%$. Later the rate of unemployment steadily decreased, falling to $6.61 \%$ in the third quarter of 2008 . The observed fall of unemployment was likely attributable to high migration from Poland [Grabowska-Lusińska and Okólski, 2008]. The third wave of unemployment was the weakest, with the rate rising mildly until it reached its peak in the first quarter of 2013. Ever since then, unemployment in Poland has been falling, hitting a low of $4.48 \%$ in the fourth quarter of 2017, its lowest level since 1992.

Figure 1. Unemployment rate (UR) in Poland 1992Q2-2017Q4

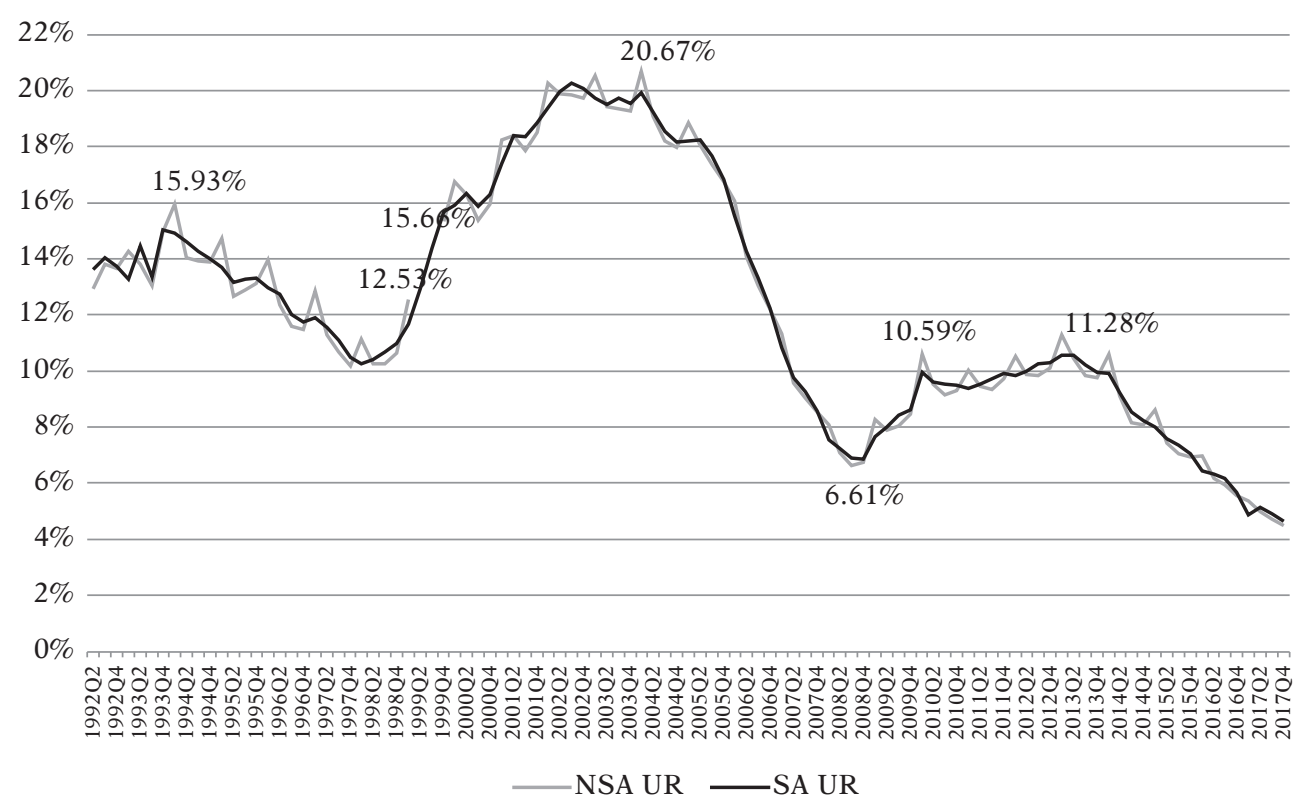

Source: Own calculations based on Central Statistical Office [2018 a, b] data.

In the empirical study, a model based on 103 seasonally adjusted observations from the entire period, i.e. 1992Q2-2017Q4, was estimated.

\section{Empirical Results}

In order to adequately describe the short-run dynamics of the unemployment rate in Poland, $p=6$ was set. Subsequently, the choice of the lag length based on the Akaike Information Criterion (AIC) and Bayes-Schwarz Information Criterion (BIC) was tested. The results of the conducted test given in Table 1 indicate that the optimal lag order is $\mathrm{p}=2$.

Table 2 presents the estimation results for the linear model, which was estimated by OLS. The ADF statistic for $\rho$ is -1.990 . Therefore, the conclusion is that the linear representation of unemployment has a unit root. 
Table 1. The choice of lag length for the ADF test

\begin{tabular}{|c|c|c|}
\hline Lag order & AIC & BIC \\
\hline 1 & -765.82 & -755.36 \\
\hline 2 & -770.65 & -757.63 \\
\hline 3 & -763.17 & -747.60 \\
\hline 4 & -759.87 & -741.77 \\
\hline 5 & -761.46 & -740.86 \\
\hline 6 & -768.46 & -745.38 \\
\hline
\end{tabular}

Source: Own calculations.

Table 2. Linear model

\begin{tabular}{|l|c|c|c|}
\hline \multicolumn{1}{|c|}{ Variable } & Estimate & Standard error & t-ratio \\
\hline constant & 0.005 & 0.003 & $1.985^{* *}$ \\
\hline trend & $-3.82 \mathrm{e}-05$ & $2.13 \mathrm{e}-05$ & $-1.789^{*}$ \\
\hline $\mathrm{y}_{\mathrm{t}-1}$ & -0.029 & 0.015 & $-1.990^{1}$ \\
\hline$\Delta \mathrm{y}_{\mathrm{t}-1}$ & 0.304 & 0.094 & $3.223^{* * *}$ \\
\hline$\Delta \mathrm{y}_{\mathrm{t}-2}$ & -0.361 & 0.095 & $3.797^{* * *}$ \\
\hline
\end{tabular}

Note: $* * * * * *$ indicate significance at $1 \%, 5 \%$ and $10 \%$ levels respectively. ${ }^{1}$ ADF statistic. Source: Own calculations.

In the case of the TAR model, the AIC and BIC (Table 3) were calculated in order to choose the appropriate lag order. Once again, the $p=6$ was started from. However, in that case, there was no need for a further reduction of the lag order.

Table 3. The choice of lag order for the TAR process

\begin{tabular}{|c|c|c|}
\hline $\mathrm{p}$ & AIC & BIC \\
\hline 1 & -782.00 & -771.54 \\
\hline 2 & -788.00 & -774.97 \\
\hline 3 & -784.00 & -768.43 \\
\hline 4 & -778.00 & -759.90 \\
\hline 5 & -788.00 & -767.40 \\
\hline 6 & -806.00 & -782.92 \\
\hline
\end{tabular}

Source: Own calculations.

The following issue to be resolved in this study is whether the TAR model is a better representation of the unemployment rate than the linear model. Wald statistics with an assumption that $m$ is known and fixed are presented in Table 4. The null hypothesis of no threshold is only rejected at a $1 \%$ level of significance in the case of $m=3$. However, this testing methodology is criticised because it is conditional on $m$, while $m$ is generally unknown. Therefore, the 
bootstrap $p$-value was recalculated, while allowing for the estimation of $m$. It indicates that the TAR model with $m=3$ is still statistically significant, though at $5 \%$ significance level. Therefore, further calculations will be presented only for that model.

Table 4. Bootstrap threshold test

\begin{tabular}{|c|c|c|c|c|c|}
\hline $\mathrm{M}$ & $\mathrm{W}_{\mathrm{t}}$ & $10 \% \mathrm{CV}$ & $5 \% \mathrm{CV}$ & $1 \% \mathrm{CV}$ & $p$-value \\
\hline 1 & 29.3 & 24.9 & 27.8 & 34.6 & 0.043 \\
\hline 2 & 11.8 & 25.2 & 28.2 & 34.9 & 0.928 \\
\hline 3 & 38.1 & 25.5 & 28.5 & 34.5 & 0.0009 \\
\hline 4 & 14.5 & 25.9 & 28.7 & 34.9 & 0.809 \\
\hline 5 & 28.1 & 26.1 & 28.8 & 35.3 & 0.095 \\
\hline 6 & 24.2 & 26.2 & 29.2 & 35.4 & 0.217 \\
\hline
\end{tabular}

Source: Own calculations.

Table 5 shows the estimation results of the TAR model. In particular, the obtained estimate of $\lambda$ indicates that $80 \%$ of the observations lie in regime 1 , where $y_{t-1}-y_{t-4}<0.967$ percentage points (p.p.), and $20 \%$ of the observations lie in regime 2 , where $y_{t-1}-y_{t-4} \geq 0.967 \mathrm{p}$. p.

Table 5. Least squares estimates of threshold model

\begin{tabular}{|c|c|c|c|c|}
\hline \multirow[b]{3}{*}{ Variable } & \multicolumn{4}{|c|}{$\hat{m}=3, \hat{\lambda}=0.967$ p.p. } \\
\hline & \multicolumn{2}{|c|}{$Z_{t-1}<\lambda$} & \multicolumn{2}{|c|}{$Z_{t-1} \geq \lambda$} \\
\hline & Estimate & Std. Error & Estimate & Std. Error \\
\hline Constant & $0.00626^{* * *}$ & 0.00238 & 0.0203 & 0.789 \\
\hline trend & $-3.75 \mathrm{e}-005^{* *}$ & $1.84 \mathrm{e}-005$ & $-0.000224 * * *$ & $7.47 \mathrm{e}-005$ \\
\hline $\mathrm{y}_{\mathrm{t}-1}$ & -0.0381 & 0.0137 & -0.0311 & 0.0349 \\
\hline$\Delta \mathrm{y}_{\mathrm{t}-1}$ & $0.557^{* * *}$ & 0.121 & -0.0176 & 0.169 \\
\hline$\Delta \mathrm{y}_{\mathrm{t}-2}$ & -0.043 & 0.115 & -0.244 & 0.152 \\
\hline$\Delta \mathrm{y}_{\mathrm{t}-3}$ & 0.154 & 0.114 & $-0.743^{* * *}$ & 0.193 \\
\hline$\Delta \mathrm{y}_{\mathrm{t}-4}$ & 0.00193 & 0.102 & $0.427 *$ & 0.154 \\
\hline$\Delta \mathrm{y}_{\mathrm{t}-5}$ & 0.131 & 0.0898 & $-0.326^{*}$ & 0.173 \\
\hline$\Delta \mathrm{y}_{\mathrm{t}-6}$ & 0.120 & 0.0904 & $-0.364^{* *}$ & 0.182 \\
\hline
\end{tabular}

Note: As in Table 1.

Source: Own calculations.

The next question posed in this study concerns the presence of a threshold unit root. Threshold unit root test statistics $R_{1 t}, R_{2 t}, t_{1}$ and $t_{2}$ for a delay parameter equal to 3 were calculated. Table 4 reports the bootstrap $p$-values. The results suggest that there was no case where there was a possibility to reject the null hypothesis indicating that the rate of unemployment in Poland is 
a non-stationary process. Therefore it can be concluded that there is hysteresis of unemployment in Poland.

Table 6. Unit Root Test

\begin{tabular}{|c|c|c|c|c|}
\hline$m$ & $\mathrm{R}_{2 \mathrm{~T}}$ & $\mathrm{R}_{1 \mathrm{~T}}$ & $\mathrm{t}_{1}$ & $\mathrm{t}_{2}$ \\
\hline 3 & 0.710 & 0.898 & 0.967 & 0.560 \\
\hline
\end{tabular}

Source: Own calculations.

The unemployment rate is by construction a bounded variable scaled to range from 0 to 100 . Therefore it cannot strictly be a linear unit root process. This feature of the unemployment rate may bias the results. To explore this issue, following Caner and Hansen [2001], the four transformations of the dependent variable have been examined. The results reported in Table 9 show that the transformation of the dependent variable has partly confirmed earlier conclusions. In all cases, the linear ADF statistic indicates that the rate of unemployment in Poland is a non-stationary process. However, it was found that the hypothesis of linearity cannot be rejected in favour of threshold nonlinearity in the case of the first and second types of transformation of the dependent variable, while it can be rejected at a 5\% level of significance for the third and fourth types of transformation. Furthermore, the results of unit root tests confirm previous findings that the null hypothesis cannot be rejected, implying the hysteresis of unemployment in Poland.

Table 7. Results for alternative specifications of dependent variable

\begin{tabular}{|l|c|c|c|c|}
\hline \multicolumn{1}{|c|}{ Dependent variable } & ADF statistic & Log-Likelihood & $\mathrm{W}_{\mathrm{T}} p$-value & $\mathrm{R}_{1 \mathrm{~T}} p$-value \\
\hline $\ln \left(\mathrm{UR}_{\mathrm{t}} /\left(1-\mathrm{UR}_{\mathrm{t}}\right)\right)$ & -1.92 & 417.00 & 0.07 & 0.380 \\
\hline $\ln \left(\mathrm{UR}_{\mathrm{t}}\right)$ & -1.92 & 417.00 & 0.08 & 0.369 \\
\hline$-100 \ln \left(1-\mathrm{UR}_{\mathrm{t}} / 100\right)$ & -2.47 & 412.00 & 0.03 & 0.509 \\
\hline $100\left(\exp \left(\mathrm{UR}_{\mathrm{l}} / 100\right)-1\right)$ & -2.47 & 412.00 & 0.03 & 0.503 \\
\hline
\end{tabular}

Source: Own calculations.

The obtained results are in line with previous studies on Polish unemployment conducted by Arendt [2006] and Mielich-Iwanek [2009], who also found hysteresis to be present in unemployment in Poland. However, the reported results are contrary to the findings of Yilanci [2008], who argues that the unemployment rate in Poland is a nonlinear but stationary process, while Akdoğan [2017] suggests that it is linear and stationary. Similarly, León-Ledesma and McAdam [2004] claim that the unemployment rate in Poland is stationary.

According to the results obtained by Akdoğan [2017], the rate of unemployment is a nonlinear and non-stationary series in the following 13 countries: Bulgaria, France, Germany, Iceland, Italy, Japan, Luxemburg, Malta, Norway, Portugal, Slovenia, Sweden, and the UK. 


\section{Conclusions}

In this study, it was found that the unemployment rate in Poland is a nonlinear process. From an economic policy point of view, the nonlinearity of unemployment has an important policy implication, since, as Bean [1997] points out, unemployment does not respond in the same way as expansionary and contractionary shocks. This pattern is explained by Hamermesh and Pfann [1996], who found asymmetries in the adjustment costs of labour faced by companies. The costs of hiring or dismissing could be asymmetric due to search costs or training costs. At the macro level, this implies that if the cost of positive adjustments (hiring) is higher than the cost of negative adjustments (dismissing), it will take longer to rise from a trough to a peak, and additionally the troughs will be deeper.

What's more, results derived from linear and nonlinear TAR models do not support the natural rate of unemployment theory. Therefore, all the reported findings suggest that there is hysteresis of unemployment in Poland, which means that all shocks to unemployment have permanent effects with no tendency to revert to a long-run steady state or the natural rate. That has important economic policy implications, since it is difficult to forecast future movements in the unemployment rate due to the fact that it will not return to its natural rate.

Moreover, when the rate of unemployment is stationary, it is possible to forecast changes in the inflation rate on the basis of the Phillips curve. Still, in the case of the non-stationary unemployment rate, this leads to difficulties in obtaining an appropriate growth rate of demand, one compatible with the inflation target.

Further extensions of this study may include the application of the threshold vector error-correction model (VECM), such as in Hansen and Seo [2002], who used threshold VECM with one cointegrating vector and a threshold effect on the error-correction term. Also, the conclusions from this study may be verified using panel unit root tests. The panel may, for example, cover Central and Eastern European (CEE) countries. A similar study was performed by LeónLedesma and McAdam [2004], but it was based on data from 1991 to 2001. Therefore, their data covered the transition period in the CEE region. The main conclusion from the above-mentioned study was that the unemployment rate in those countries was stationary with multiple equilibriums. It would be interesting to check whether that conclusion is still valid.

\section{References}

Akdoğan K. [2017], Unemployment hysteresis and structural change in Europe, Empirical Economics, vol. 53(4): 1415-1440.

Arendt Ł. [2005], Próba oszacowania NAIRU dla Polski, Gospodarka Narodowa, vol. 5-6: 1-23. Arendt Ł. [2006], Czy w Polsce występuje efekt histerezy bezrobocia?, Gospodarka Narodowa, vol. 11-12: 25-46. 
Bartosik K. [2012], Popytowe i podażowe uwarunkowania polskiego bezrobocia, Gospodarka Narodowa, vol. 11-12: 25-57.

Bartosik K., Mycielski J. [2016], Dynamika płac a długotrwałe bezrobocie w polskiej gospodarce, Bank i Kredyt, vol. 47(5): 435-462.

Bean Ch.R. [1997], The role of demand management policies in reducing unemployment, Proceedings - Economic Policy Symposium - Jackson Hole, Federal Reserve Bank of Kansas City, January: 99-167.

Blanchard O., Summers L.H. [1986], Hysteresis and the European unemployment problem, NBER Macroeconomics Annual, MIT Press.

Caner M., Hansen B.E. [2001], Threshold autoregression with a unit root, Econometrica, vol. 69(6): 1555-1596.

Central Statistical Office [2018a], Aktywność ekonomiczna ludności Polski (III kwartał 2017), Labour Force Survey in Poland (3 rd quarter 2017), Warszawa.

Central Statistical Office [2018b], Kwartalna informacja o rynku pracy $w$ czwartym kwartale 2017 roku (dane wstępne).

Friedman M. [1968], The role of monetary policy, American Economic Review 58(1), pp. 1-17.

Grabowska-Lusińska I., Okólski M. [2008], Migracja z Polski po 1 maja 2004 r.: jej intensywność i kierunki geograficzne oraz alokacja migrantów na rynkach pracy krajów Unii Europejskiej, CMR Working Paper, no. 33/91.

Hamermesh D.S., Pfann G.A. [1996], Adjustment costs in factor demand, Journal of Economic Literature, vol. 34(3): 1264-1292.

Hansen B.E. [1996], Inference when a nuisance parameter is not identified under the null hypothesis, Econometrica, vol. 64(2): 413-430.

Hansen B.E. [1997], Inference in TAR models, Studies in Nonlinear Dynamics and Econometrics, vol. 2(1): 1-14.

Hansen B.E. [2011], Threshold autoregression in economics, Statistics and Its Interface, no. 4: 123-127.

Hansen B.E., Seo B. [2002], Testing for two-regime threshold cointegration in vector error-correction models, Journal of Econometrics, vol. 110(2): 293-318.

Kelm R. [2009], Szacunek NAIRU/NAWRU dla Polski na podstawie krzywej Phillipsa, 1996: 1-2006:2, in: Kwiatkowska W. (ed.), Bezrobocie równowagi w gospodarce polskiej. Szacunki, tendencje i determinant, Wydawnictwo Uniwersytetu Łódzkiego, Łódź.

Kwiatkowski E. [2002], Strukturalne determinanty naturalnej stopy bezrobocia, Bank $i$ Kredyt, vol. 33 (11-12): 149-155.

Lee Ch-Ch., Chang Ch-P. [2008], Unemployment hysteresis in OECD countries: centurial time series evidence with structural breaks, Economic Modelling, vol. 25(2): 312-325.

León-Ledesma M.A., McAdam P. [2004], Unemployment, hysteresis and transition, Scottish Journal of Political Economy, vol. 51(3), pp. 377-401.

Leszkiewicz-Kędzior K., Welfe W. [2013], Szacunek naturalnej stopy bezrobocia dla Polski, Acta Universitatis Lodzensis, vol. 281: 93-107.

Meng M., Strazicich M.C., Lee J. [2017], Hysteresis in unemployment, Empirical Economics, vol. 53(4): 1399-1414. 
Mielich-Iwanek K. [2009], Polski rynek pracy w świetle teorii histerezy, Prace Naukowe Uniwersytetu Ekonomicznego we Wroctawiu, vol. 76: 122-132.

Phelps E.S. [1967], Phillips curves, expectations of inflation and optimal unemployment over time, Economica, vol. 34(135): 254-281.

Phelps E.S. [1968], Money-wage dynamics and labour-market equilibrium, Journal of Political Economy, vol. 76(4): 678-711.

Roszkowska S. [2013], Ceny, płace i sytuacja na rynku pracy w Polsce - analizy oparte na modelu wektorowej korekty błędem, Materiaty i Studia NBP, no. 290.

Socha M., Sztanderska U. [2000], Strukturalne podstawy bezrobocia w Polsce, Wydawnictwo Naukowe PWN, Warszawa.

Tong H. [2015], Threshold models in time series analysis - some reflections, Journal of Econometrics, vol. 189(2): 485-491.

Wojtyna A. [1994], Czy Polsce grozi efekt histerezy? Gospodarka Narodowa, no. 9: 1-10.

Yilanci V. [2008], Are unemployment rates nonstationary or nonlinear? Evidence from 19 OECD countries, Economics Bulletin, vol. 3(47): 1-5. 


\section{Dynamika bezrobocia w Polsce w latach 1992-2017}

Streszczenie: Celem artykułu jest weryfikacja hipotez dotyczących dynamiki bezrobocia dla danych kwartalnych gospodarki Polski. Wyróżnia się teorię naturalnej stopy bezrobocia (NAIRU) oraz teorię histerezy. Według teorii NAIRU istnieje swoista dla danej gospodarki stopa bezrobocia, a wszelkie odchylenia od jej poziomu są czasowe i gospodarka samoczynnie powraca do stanu równowagi. Według teorii histerezy wstrząsy w poziomie bezrobocia obserwowanego trwale wpływają na poziom naturalnej stopy bezrobocia. Testowanie tych alternatywnych teorii sprowadza się do testowania występowania pierwiastka jednostkowego. Jeżeli proces jest stacjonarny, wtedy można odrzucić teorię histerezy. W przeciwnym wypadku należy zaakceptować występowanie efektu histerezy bezrobocia. Zastosowanie progowego modelu autoregresyjnego do kwartalnych danych o bezrobociu w Polsce latach od 1992 (Q2) do 2017 (Q4) potwierdziło efekt histerezy bezrobocia.

Słowa kluczowe: bezrobocie, histereza bezrobocia, progowy model autoregresyjny, testy pierwiastka jednostkowego

Kody klasyfikacji JEL: C22, J64

Artykuł nadesłany 25 kwietnia 2018 r., zaakceptowany 16 stycznia 2019 r.

Unless stated otherwise all the materials on the website are available under the Creative Commons Attribution 4.0 International license.

Some rights reserved to the SGH Warsaw School of Economics.

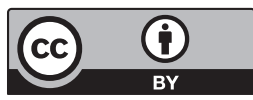

